\title{
Oxidative Stress Biomarkers as Prognostic Indicators of Severity in Patients With Dengue
}

\author{
Raimundo Castro-Orozco ${ }^{1}$, Adolfo Marcelo ${ }^{2}$, María Paquita Garcia ${ }^{2}$, Nancy Merino ${ }^{2}$, Oscar \\ Escalante-Maldonado ${ }^{2}$, Cinthya Mora ${ }^{3}$, Marlon Rodriguez ${ }^{1} \&$ Nelson Alvis-Guzman ${ }^{4}$ \\ ${ }^{1}$ Group of Biomedical Research, Grupo de Investigaciones Biomédicas-GIB, Universidad de San Buenaventura, \\ Cartagena, Colombia \\ ${ }^{2}$ National Institute of Public Health of Peru, Cartagena, Colombia \\ ${ }^{3}$ Universidad Simon Bolivar, Barranquilla, Colombia \\ ${ }^{4}$ Universidad de Cartagena, and Universidad de la Costa-CUC, Cartagena, Colombia \\ Correspondence: Raimundo Castro-Orozco, Universidad de San Buenaventura, Cartagena, Calle Real de Ternera \\ No. 30-966 - PBX 653 5555, Cartagena, Colombia. E-mail: raimundo_castro_orozco@hotmail.com, \\ rcastro@usbctg.edu.co
}

Received: October 10, 2018 Accepted: November 8, 2018 Online Published: December 13, 2018

doi:10.5539/gjhs.v11n1p46 URL: https://doi.org/10.5539/gjhs.v11n1p46

\begin{abstract}
There is evidence for the role of oxidative stress in severe dengue pathogenesis. However, previous observational studies presents certain methodological limitations, which may affect its internal and external validity. This study was a case-control analysis of patients with severe dengue and dengue with warning signs, to evaluate the serum protein carbonyls-PCOs and lipid hydroperoxides-LOOHs levels and activities of superoxide dismutases-SODs (MnSOD, $\mathrm{Cu} / \mathrm{ZnSOD}$ and total SOD), as potential prognosis indicators of severity in dengue patients, using binary logistic regression analysis and strategy of double cross-validation. Therefore, the study population was subdivided into a derivation group (pediatric patients, Barranquilla-Colombia) and an external validation group (children and adults patients, National Institute of Health of Peru). PCOs was the only oxidative stress markers that showed a strongest association with the severity of dengue, both in children and adults. In the derivation group, the optimal cut-off point was estimated at $5.29 \mathrm{nmol} / \mathrm{mg}$ of protein, and in the external validation group, it was 5.77 $\mathrm{nmol} / \mathrm{mg}$ of protein. The prognostic models based on these two diagnostic thresholds showed a high discriminatory capacity of dengue severity, external reproducibility, geographic transportability, and typical characteristics of diagnostic validity and safety of screening tests.
\end{abstract}

Keywords: dengue, severe dengue, oxidative stress, protein carbonylation, superoxide dismutase, manganese; superoxide dismutase, $\mathrm{Cu}-\mathrm{Zn}$, lipid hydroperoxide, prognosis

\section{Introduction}

The World Health Organization-WHO considers dengue one of the 17 neglected tropical diseases (Molyneux, 2013), present in more than 100 countries, with reports of 50 to 100 million new cases and 20,000 deaths each year (Zapata, Cox, \& Salvato, 2014).

Since 2009, WHO has implemented a new dengue classification scheme, reporting cases such as dengue without warning signs (DwoWS), dengue with warning signs (DwWS), and severe dengue (SD) (World Health Organization, 2009). These warning signs have been proposed as prognostic criteria for severe dengue (Leo et al., 2013; World Health Organization, 2009).

Although the current case classification system (WHO-2009) overcomes, in part, the conceptual and practical limitations identified in the previous scheme (WHO-1997) (Tsai et al., 2013), this could allow arbitrary interpretations of the severity of bleeding by medical personnel as consequence of the use of less rigorous definition criteria, due to the absence of quantitative parameters and because of their independence from laboratory tests in the identification of severe cases (Halstead, 2013).

The impact of these weaknesses could be limited in the case of being able to identify biomarkers that allow the early detection of those patients with greater risk of severity, independently of sociodemographic or virological 
characteristics. Moreover, with the availability of this type of prognostic indicators, more specific and timely medical care could be provided, which is essential to improve patients' living conditions.

At this point, it is interesting to examine the conceptual relationships between dengue pathogenesis, endothelial dysfunction and oxidative stress. The most characteristic feature of cases of severe dengue and the best indicator of severity is plasma loss. This alteration of vascular permeability, which is present during the defervescence phase (4-6 days of illness), results more from endothelial dysfunction than from structural destruction of endothelial cells (Dalrymple \& Mackow, 2012). Currently, a possible association between endothelial dysfunction and the severity of dengue disease in children and adults has been reported (Yacoub et al., 2015).

There are several references that explain the relationship between endothelial dysfunction and oxidative stress (Gori \& Munzel, 2011; Pereira et al., 2008; Rodriguez-Manas et al., 2009; Silva, Pernomian, \& Bendhack, 2012; Wadsworth, 2008) that show the participation of oxidative stress in the pathogenesis of various infectious diseases (Cunha et al., 2012; Fabbri et al., 2013; Hosakote, Liu, Castro, Garofalo, \& Casola, 2009; Kalugalage et al., 2013; Levent et al., 2006; Macdonald, Galley, \& Webster, 2003; Machado, Tanowitz, \& Ribeiro, 2013; Valyi-Nagy \& Dermody, 2005; Yang et al., 2010), including dengue (Gil et al., 2004). Soundravally, et al., propose that dengue infection-induced oxidative stress would have the ability to activate the release of pro-inflammatory cytokines, including TNF- $\alpha$, participating in the pathogenesis of severe dengue, as a whole (Soundravally et al., 2014).

Despite considering lipid hydroperoxides-LOOHs and protein carbonyls-PCOs, as the most stable or specific markers to evaluate lipoperoxidation (Girotti, 1998) and oxidative protein modification (Dalle-Donne et al., 2003), respectively, there are few studies that report the behavior of these products of lipid oxidation (Gil et al., 2012; Gil et al., 2004) and of protein oxidation (Soundravally et al., 2008; Soundravally1 et al., 2008) in dengue patients.

Regarding superoxide dismutase-SOD, there are four studies that report their levels in cases of dengue (Gil et al., 2012; Gil et al., 2004; Ray, Kumar, Kapoor, Dutta, \& Batra, 1999). Only one of these reported concentrations of this antioxidant enzyme in relation to the three clinical presentations of dengue indicated by the WHO-1997 classification system (Ray et al., 1999). Although the importance of TNF- $\alpha$ in the pathogenesis of dengue is recognized (Pawitan, 2011) and its ability to selectively induce MnSOD mRNA expression both in vivo and in vitro (Wong \& Goeddel, 1988), there is no knowledge of the behavior of serum levels of this metalloenzyme in patients with dengue. Neither are known reports related to the cytosolic $\mathrm{Cu} / \mathrm{ZnSOD}$ isoform.

The aim of the study was to evaluate the serum PCOs and LOOHs concentrations and activities of SODs (MnSOD, $\mathrm{Cu} / \mathrm{ZnSOD}$ and total SOD), during the critical phase of dengue, as potential prognostic markers of severity in dengue patients.

\section{Materials and Methods}

\subsection{Cases and Controls}

A study was carried out with case and control design, in which cases were defined as patients who presented: (I) fever between the fourth and sixth day of evolution, accompanied by two or more of the following symptoms: headache, retro-ocular pain, myalgias, arthralgias, generalized pain, rash, anorexia, nausea, vomiting, petechiae, mucosal bleeding and leukopenia; (II) positive result for NS1-DENV or IgM anti-DENV and (III) requirement for specialized care in intensive care unit-ICU, due to the presence of severe manifestations of the disease, following the WHO-2009 classification scheme (World Health Organization, 2009).

The criteria for severe dengue were: (a) severe plasma leakage leading to shock or fluid accumulation with respiratory distress. (b) severe bleeding, and (c) severe organ involvement (myocarditis, encephalitis, hepatitis, acute cholecystitis, acute kidney failure, etc.) (World Health Organization, 2009).

For the selection of controls, the patients were considered: (I) with fever between the fourth and sixth day of evolution, accompanied by two or more of the following symptoms: headache, retro-ocular pain, myalgias, arthralgias, rash , anorexia, sickness, vomiting, petechiae, mucosal bleeding, and leukopenia; (II) with a positive result for NS1-DENV or anti-dengue IgM; (III) with the presence of one or more of the warning signs described in the current case classification system [5] and (IV) that did not require specialized attention in the ICU, because they do not develop severe manifestations of dengue.

Patients with comorbidities such as: severe cardiovascular disease, disorders of the haematopoeitic organs, metabolic, lung, hepatic or kidney disorders, autoimmune disease, malnutrition, pregnancy, malignancy, or comorbid infectious diseases were excluded.

\subsection{Derivation Group: pediatric patients (Barranquilla-Colombia)}

The evaluation of the prognostic capacity of the oxidative stress biomarkers was carried out in 60 serum samples 
obtained from patients (20 cases and 40 controls), under 15 years of age, served in district hospitals of Barranquilla-Colombia, during the period comprised between January 2014 and January 2016.

\subsection{External Validation Group: Pediatric and Adult Patients (Peru)}

Similarly, for the external validation of the prognostic capacity of the biomarkers, 60 serum samples were used, obtained from patients ( 20 cases and 40 controls), of all ages, referred to the Laboratory of Viral Metaxenics of the National Institute of Health of Peru, during the period between January and February 2018. Serum samples of both cases and controls were stored at $-80{ }^{\circ} \mathrm{C}$ until analysis.

\subsection{Data Collection}

We reviewed the medical records of the 60 pediatric patients, identified as a derivation group, in order to record their sociodemographic information (age, sex, and geographic origin) clinical data (days of fever onset, length of hospital stay, length of ICU stay, and symptomatology) and laboratory of interest (haemoglobin levels, hematocrit values, platelet counts, neutropenia, leukopenia, lymphopenia, monocytosis, limphocytosis, basophilia, neutrophilia, altered transaminases, BUN and creatinine levels).

In contrast, for the case of the 60 patients from the external validation group, the epidemiological records were reviewed for the registration of the variables of interest, such as: age, sex, geographic origin, days of fever onset, symptomatology, qualitative detection of NS1-DENV in serum, thrombocytopenia, and hematocrit rise $20 \%$ or more.

\subsection{DENV NS1 Antigen Capture Test (Derivation Group)}

For the qualitative detection of NS1-DENV in the serum of the pediatric patients of the derivation group, a one-step immunochromatographic test (SD Bioline Dengue NS1 Ag, Kyong, South Korea ${ }^{\circledR}$ ) was carried out, under the conditions recommended by the manufacturer.

\subsection{Anti-DENVIgM and IgG ELISA (Derivation Group)}

The detection of anti-DENV IgM and IgG in the serum of the pediatric patients of the derivation group was carried out by means of two enzyme-linked immunosorbent assays (ELISA, Vircell, Spain, References M1018 and G1018, respectively), under the conditions specified by the commercial house.

As serological evidence suggestive of secondary dengue infection, the $\operatorname{IgM} / \operatorname{IgG}$ ratio $<1.8$ was used (Alera et al., 2016). Absorbance was measured at $450 \mathrm{~nm}$ (reference filter $620 \mathrm{~nm}$ ) using a microplate reader (Stat Fax® $303 /$ PLUS, Awareness Technology, Inc. Florida, United States).

\subsection{Anti-DENV IgM and IgG ELISA (External Validation Group)}

The detection of anti-DENV IgM and IgG in the serum of the patients of the external validation group was carried out by means of two capture enzyme-linked immunosorbent assays (TARIKI-Dengue IgM, TARIKI-Dengue IgG, INS-Peru), under the conditions specified by the National Center of Biological Products of the National Institute of Health of Peru. Absorbance was measured at $450 \mathrm{~nm}$ (reference filter $620 \mathrm{~nm}$ ) using a microplate reader (PHOmo, Autobio Co., LTD).

\subsection{Viral RNA Extraction (External Validation Group)}

For the automatic and simultaneous extraction and purification of viral RNA, the magnetic particle technology of the QIAsymphony ${ }^{\circledR}$ Virus / Bacteria Mini Kit (Quiagen, Crawley, UK) was used from the serum samples of the patients from the external validation group in combination with the QIAsymphony ${ }^{\circledR}$ SP instrument, following the manufacturer's instructions, before real-time reverse transcription polymerase chain reaction (RT-PCR) analysis, since magnetic particle technology allows the purification of high quality nucleic acids that they lack proteins, nucleases and other impurities.

In each extraction and purification process, four positive controls were used (DENV-1 strain West Pac74, DENV-2 strain S16803, DENV-3 strain CH53489, DENV-4 strain TUP 360, working dilution 1/100) and a control negative (ultrapure water of PCR grade).

\subsection{Reverse Transcription-PCR for Detection of DENV, ZIKV, CHIKV, and YFV (External Validation Group)}

The simultaneous identification of DENV, zika-ZIKV virus and chikungunya-CHIKV virus, in serum samples of patients from the external validation group, was performed with a polymerase chain reaction protocol with reverse transcription in real time (Trioplex, CDC , Atlanta, USA) (Table S1). Three stages were used as amplification conditions: (I) 30 minutes at $50{ }^{\circ} \mathrm{C}, 1$ rep; (II) 2 minutes at $95{ }^{\circ} \mathrm{C}, 1$ rep; (IIIa) 15 seconds at $95{ }^{\circ} \mathrm{C}, 45$ cycles and (IIIb) 1 minute at $60^{\circ} \mathrm{C}$ [53]. 
For the molecular detection of yellow fever virus-YFV, $5.0 \mu \mathrm{L}$ of extracted and purified viral RNA was taken to undergo RT-PCT in real time in the following conditions: $12.5 \mu \mathrm{L}$ of RT-PCR master mix $(1 \mathrm{x}), 0,5 \mu \mathrm{L}$ of oligonucleotides $(10 \mu \mathrm{M})$ (Table S2), $5.0 \mu \mathrm{L}$ of magnesium sulfate $(5 \mu \mathrm{mM}), 0.5 \mu \mathrm{L}$ of enzyme transcriptase/platinum Taq mix (Invitrogen, Carlsbad, CA, USA). The following amplification conditions were used: 30 minutes at $50{ }^{\circ} \mathrm{C}, 1 \mathrm{rep} ; 2$ minutes at $94{ }^{\circ} \mathrm{C}, 1 \mathrm{rep} ; 15$ seconds at $94{ }^{\circ} \mathrm{C}, 40 \mathrm{rep} ; 30$ seconds at $55^{\circ} \mathrm{C}, 40$ rep; 2 minutes at $72{ }^{\circ} \mathrm{C}, 40$ rep; 10 minutes at $72{ }^{\circ} \mathrm{C}, 1$ rep.

\subsection{Reverse Transcription-PCR for Serotyping of DENVs (External Validation Group)}

Briefly, $10.0 \mu \mathrm{L}$ of extracted viral RNA was used as template for the identification of DENV serotype, using the protocol described by Lanciotti, et al. (Lanciotti, Calisher, Gubler, Chang, \& Vorndam, 1992), with the oligonucleotides described in Table S1. Reverse transcription of $10 \mathrm{~min}$ at $50{ }^{\circ} \mathrm{C}$ was followed by 45 cycles of amplification in a Rotor-Gene Q real time PCR cycler (Qiagen).

\subsection{Serum Protein Carbonyls Estimation}

Materials and reagents of the Protein Carbonyl Colorimetric Assay Kit (catalog No. 10005020; Cayman Chemical Company, Ann Arbor, MI) were used for quantitative determination of PCOs in serum samples, using the alkaline method, which consists in a neutralization with $6 \mathrm{M} \mathrm{NaOH}$ subsequent to the step of derivatization with 2,4-DNPH to change the absorbance of carbonyl conjugated hydrazone at $450 \mathrm{~nm}$ (Mesquita et al., 2014).

Briefly, a mixture was made from equal volumes between 2,4-DNPH and serum sample (working dilution, 1:10). As a blank, an equal-volume mixture of 2,4-DNPH and phosphate buffered saline $(\mathrm{pH}=7.2)$ was used. After 10 minutes of incubation at room temperature, in the dark, $200 \mu \mathrm{L}$ of $6 \mathrm{M} \mathrm{NaOH}$ was added. Then, it was incubated for 10 minutes at room temperature (Mesquita et al., 2014). Absorbance was measured at $450 \mathrm{~nm}$ (reference filter $620 \mathrm{~nm}$ ) using a microplate reader (PHOmo, Autobio Co., LTD).

The amount of serum protein was calculated from a bovine serum albumin (BSA) standard curve $(0.2-2.0 \mathrm{mg} / \mathrm{mL})$ dissolved in guanidine hydrochloride and read at $280 \mathrm{~nm}$.

\subsection{Serum Manganese Superoxide Dismutase, Cu/Zn Superoxide Dismutase, and Total Superoxide Dismutase Estimations}

Materials and reagents of the Superoxide Dismutase Assay Kit (catalog No. 706002, Cayman Chemical Company, Ann Arbor, MI) were used for determination of SODs activities. The addition of potassium cyanide-KCN ( $3 \mathrm{mM})$ to the assay allowed the inhibition of both $\mathrm{Cu} / \mathrm{ZnSOD}$ and extracellular SOD, in order to detect only mitochondrial superoxide dismutase-MnSOD activity.

Briefly, in the preparation of the wells for the SOD standards, $200 \mu \mathrm{L}$ of the diluted radical detector and $10 \mu \mathrm{L}$ of one of the seven SOD standards available in the kit $(0-0.25 \mathrm{U} / \mathrm{mL})$ were added. For the preparation of the wells for the samples, $190 \mu \mathrm{L}$ of the diluted radical detector, $10 \mu \mathrm{L}$ of $3 \mathrm{mM} \mathrm{KCN}$ and $10 \mu \mathrm{L}$ of the patient's serum (working dilution 1:5) were added. To determine the enzymatic activity of total SOD, $200 \mu \mathrm{L}$ of the diluted radical detector and $10 \mu \mathrm{L}$ of the patient's serum (working dilution, 1:5) were added. The reaction was started with the addition of $20 \mu \mathrm{L}$ of diluted xanthine oxidase. To the blank, $20 \mu \mathrm{L}$ of the sample buffer available in the kit was added. After shaking for a few seconds, it was incubated for 20 minutes at room temperature.

The total enzymatic activity of SOD could be determined in absence of inhibitor and with the difference between activity values of total SOD and MnSOD, the enzymatic activity of the cytosolic $\mathrm{Cu} / \mathrm{ZnSOD}$ isoform could be estimated. Absorbance was measured at $450 \mathrm{~nm}$ (reference filter $620 \mathrm{~nm}$ ) using a microplate reader (PHOmo, Autobio Co., LTD). The interassay coefficient of variation was $4.6 \%$, obtained with the calibrators available in the kit.

\subsection{Serum Lipid Hydroperoxides Estimation}

Serum LOOHs levels were measured by colorimetric assays using a commercially available kit according to manufacturer's instructions (Lipid Hydroperoxyde Assay Kit, catalog no.705003; Cayman Chemical Company, Ann Arbor, MI). Initially, the serum samples (working dilution, 1:20) were extracted with ethanol and chloroform. Then, $300 \mu \mathrm{L}$ of the sample extract, $300 \mu \mathrm{L}$ of the chromogen and $300 \mu \mathrm{L}$ of the ethanol-chloroform mixture were added. A calibration curve was made with the eight standards of LOOHs (13-hydroperoxyoctadecadienoic acid ethanolic solution, 13-HpODE, 0.0-5.0 $\mu \mathrm{M}$ ) available in the kit. Absorbance was measured at $492 \mathrm{~nm}$ (reference filter $620 \mathrm{~nm}$ ) using a microplate reader (PHOmo, Autobio Co., LTD). The interassay coefficient of variation was $5.3 \%$, obtained with the calibrators available in the kit. 


\subsection{Statistical Analysis}

Normality assessed with the Shapiro-Wilks test, one of the tests of goodness of fit with greater statistical power (Yap \& Sim, 2011). Numerical variables are expressed as the mean and standard deviation, when it presented normal distribution and the median and lower and upper quartiles when presented non-normal distribution.

Statistical associations between research variables and the severity of dengue were identified with Fisher's exact test, accompanied by the respective effect size. Comparisons between two groups for serum biomarker concentrations were performed using Student's t-test of independent samples or the Mann-Whitney U test. Also, the respective effect size was estimated (Cohen'd or Rosenthal's correlation coefficient, respectively) (Gaskin \& Happell, 2014).

Receiver curve (ROC) analysis was performed to find sensitivity and specificity for every potential cut-off values of each biomarker. To identify the optimum cut-off value, maximum value of the Youden Index (J) was used. Within the derivation group (20 cases: SD and 40 controls: DwWS), binary logistic regression was used to estimate the effect of prognostic variables or factors (dichotomised biomarker) on occurrence of severe dengue, with variable entered stepwise using the forward conditional likelihood ratio with $\mathrm{p}$-in $\leq 0.05$ and $\mathrm{p}$-out $\geq 0.10$.

We tested the goodness-of-fit for final models using Hosmer-Lemeshow test. A bootstrap method was used to internal validation of prognostic models. Each bootstrap sample was obtained by randomly sampling 10000 times from the data sets. The prognostic model was refitted and tested on the original sample to obtain an estimate of predictive accuracy corrected for bias (overoptimism). Calibration and discrimination of the models were assessed with the ROA's efficient score statistic and with c-statistic, respectively (Nuñez, 2011). The criteria of Swets (Swets, 1988) were used to assess the accuracy of the sensitivity and specificity values. The AUCs of the different prognostic models were compared using the statistical test of Hanley and McNei (Hanley \& McNeil, 1983).

All p-values estimated in the hypothesis tests were interpreted using the criteria of Sterne and Smith (Sterne \& Davey Smith, 2001). However, to establish statistically significant differences between two independent groups, 95 percentage confidence intervals of the difference (C195\% diff $)$ were interpreted between independent proportions, means or medians.

Final prognostic model was validated in two sets of serum samples obtained of dengue patients (20 cases: SD and 40 controls: DwWS) notified to the National Institute of Health of Peru (geographical external validation). Within the external validation group, calibration and discrimination measures of final prognostic model were estimated using the same methods of statistical inference. Finally, the double cross-validation strategy was also used (Osborne, 2000).

Data were analyzed using four statistical software: IBM® SPSS ${ }^{\circledR}$ Statistics version 23.0 (IBM Corp, Armonk, New York), GraphPad PRISM ${ }^{\circledR}$ version 6.01 (GraphPad software, San Diego, CA), EpiDat 3.1® (General Directorate of Innovation and Public Health Management, Xunta de Galicia, Spain, Pan American Health Organization and Higher Institute of Medical Sciences of Havana) and Stata ${ }^{\circledR}$ version 14.2 (Stata Corporation, College Station, TX, USA).

\subsection{Ethical Statements}

The present study was reviewed and approved by the IPS Universitaria Barranquilla-Colombia (Office of approval 10-02-2016-IPS Universitaria-Barranquilla) and by the National Institute of Health of Peru (Office of approval 535-2017-OGITT-OPE / INS).

\section{Results}

\subsection{Clinical Characteristics of Derivation Group}

All the pediatric patients belonging to this group came from the city of Barranquilla-Colombia and presented the same median for age (11 years; IQR: 10 to 13), both in the cases and in the controls. Despite a predominance of males $(63.3 \%$, CI95\% 50.7\% to $74.4 \%)$ among derivation group, we found no evidence of statistical association or significant difference between sex and the severity of dengue ( $\mathrm{p}=0.573$; CI95\% $\%_{\text {diff }}-15.8 \%$ to $31.8 \%$ ).

The median number of days after the onset of fever in cases was similar to that in controls ( 5 days vs. 4 days; $\mathrm{p}=0.192$; CI $95 \%_{\text {diff }}-1.0$ to 0.0$)$. In contrast, the median length of hospital stay significantly differed between cases and controls (5 days vs. 3 days, respectively; CI95\% $\%_{\text {diff }} 1.0$ to 3.0). At the same time, we found a strong statistical association between the severity of dengue and the number of days of hospital stay (Rosenthal's correlation coefficient $=0.6 ; \mathrm{p}<0.0001$ ).

Furthermore, there was no statistical association between clinical symptoms and severe dengue, except for 
asthenia ( $\mathrm{p}=0.036$; $\mathrm{OR}=6.3$; $\mathrm{CI} 95 \% 1.1$ to 36.3 ). Likewise, a strong statistical association was found between thrombocytopenia and severity of dengue ( $\mathrm{p}=0.001$; OR=12.0; CI95\% 3.4 to 41.8 ). In relation to serum transaminases levels (glutamic-pyruvic transaminase-GPT and glutamic-oxaloacetic transaminase-GOT), elevated concentrations of these liver enzymes showed a strong statistical association to severe dengue in this group of pediatric patients ( $\mathrm{p}=0.0007$; $\mathrm{OR}=8.5$; $\mathrm{CI} 95 \% 2.5$ to 28.9 and $\mathrm{p}=0.0001 ; \mathrm{OR}=13.8$; $\mathrm{CI} 95 \% 3.8$ to 49.6 , respectively).

Approximately $50.0 \%$ (CI95\% $\%_{\text {diff }} 29.9 \%$ to $70.1 \%$ ) of the cases and $30.0 \%$ (CI95\% $\%_{\text {diff }} 18.1 \%$ to $45.4 \%$ ) of the controls presented serological evidence suggestive of DENV reinfection, but without showing statistically significant differences between them ( $\mathrm{p}=0.161$; $\mathrm{CI} 95 \% \%_{\text {diff }}-5.3 \%$ to $\left.43.4 \%\right)$. The rest of the variables studied in derivation group are presented in Table 1.

\subsection{Clinical Characteristics of External Validation Group}

In this group, the median for the age of the cases was comparable to that in controls ( 20 years vs. 16 years, respectively; $\mathrm{p}=0.347$; $\mathrm{CI} 95 \%_{\text {diff }}-10.0$ to 4.0 ). Moreover, there was also no statistically significant difference in the distribution of age groups among cases and controls ( $\leq 15$ years of age vs. $>15$ years of age: $C 195 \%$ diff $-6.4 \%$ to $41.4 \% ; \mathrm{p}=0.174)$. Likewise, we found no evidence of statistical association or significant difference between sex and the severity of dengue ( $\mathrm{p}=0.176$; CI95\% $\%_{\text {diff }}-6.3 \%$ to $42.7 \%$ ).

Although a moderate statistical association was observed between the presence of severe dengue and the number of days of illness (Rosenthal's correlation coefficient $=0.3 ; \mathrm{p}=0.031$ ), a statistically significant difference could not be found when comparing the cases and controls ( 5 days vs. 4 days, respectively; CI95\% $\%_{\text {diff }}-1.0$ to 0.0 ).

The only symptoms that showed a strong statistical association with the severity of dengue were: asthenia $(\mathrm{p}=0.004 ; \mathrm{OR}=16.7$; CI95\% 2.3 to 113.1) and lethargy ( $\mathrm{p}=0.0004 ; \mathrm{OR}=15.6$; CI95\% 2.9 to 82.8), however, the presence of respiratory distress showed a moderate statistical association with severe dengue $(\mathrm{p}=0.042$; OR $=3.4$; CI95\% 1.1 to 10.7). The rest of the variables evaluated in the external validation group are presented in Table 2.

Approximately 55\% (CI95\% 34.2\% to $74.2 \%$ ) of the cases and $40 \%$ (CI95\% 26.4\% to 55.4\%) of the controls presented serological evidence suggestive of DENV reinfection, but without show statistically significant differences between them ( $\mathrm{p}=0.288$; C195\% $\%_{\text {diff }}-10.9 \%$ to $38.5 \%$ ). DENV-2 was the only DENV serotype identified (cases: $25.0 \%$; CI95\% $11.2 \%$ to $46.9 \%$; controls: $30.0 \%$; CI95\% 18.1\% to 45.4\%). ZIKV RNA, CHIKV RNA and YFV RNA were not detected in any of the serum samples.

Table 1. Clinical and laboratory characteristics of pediatric patients with severe dengue and dengue with warning signs. Derivation group, Barranquilla-Colombia, 2014-2016

\begin{tabular}{llll}
\hline Variables & $\begin{array}{l}\text { Severe Dengue } \\
\mathbf{n}(\%)\end{array}$ & $\begin{array}{l}\text { DwWS } \\
\mathbf{n}(\%)\end{array}$ & p-value* \\
\hline Fever & $20(100.0)$ & $40(100.0)$ & $\mathrm{NE}$ \\
Lumbar backache & $10(50.0)$ & $24(60.0)$ & 0.582 \\
Retro-orbital pain & $15(75.0)$ & $28(70.0)$ & 0.769 \\
Asthenia & $5(25.0)$ & $2(5.0)$ & 0.036 \\
Persistent vomiting & $10(50.0)$ & $24(60.0)$ & 0.582 \\
Lethargy & $0(0.0)$ & $6(15.0)$ & $\mathrm{NE}$ \\
Petechia & $2(10.0)$ & $1(2.5)$ & 0.255 \\
Rash & $5(25.0)$ & $10(25.0)$ & 0.998 \\
Swelling & $1(5.0)$ & $3(7.5)$ & 0.998 \\
Epistaxis & $4(20.0)$ & $4(10.0)$ & 0.422 \\
Hematemesis & $2(10.0)$ & $0(0.0)$ & $\mathrm{NE}$ \\
Abdominal pain & $13(65.0)$ & $21(52.5)$ & 0.416 \\
Pleural effusion & $3(15.0)$ & $0(0.0)$ & $\mathrm{NE}$ \\
Hemoglobin levels $<12 \mathrm{~g} / \mathrm{dL}$ & $3(15.0)$ & $14(35.0)$ & 0.136 \\
\hline
\end{tabular}




\begin{tabular}{llll}
\hline Variables & $\begin{array}{l}\text { Severe Dengue } \\
\mathbf{n}(\%)\end{array}$ & $\begin{array}{l}\text { DwWS } \\
\mathbf{n}(\%)\end{array}$ & p-value* \\
\hline HCT rise 20\% or more & $9(45.0)$ & $11(27.5)$ & 0.246 \\
DLC (to hospital admission) & & & \\
Thrombocytopenia & $15(75.0)$ & $8(20.0)$ & 0.001 \\
Neutropenia & $4(20.0)$ & $13(32.5)$ & 0.375 \\
Lymphopenia & $4(20.0)$ & $13(32.5)$ & 0.375 \\
Monocytosis & $7(35.0)$ & $12(30.0)$ & 0.772 \\
Lymphocytosis & $5(25.0)$ & $18(45.0)$ & 0.166 \\
Basophilia & $3(15.0)$ & $6(15.0)$ & 0.998 \\
Neutrophilia & $6(30.0)$ & $12(30.0)$ & 0.998 \\
Altered BUN levels & $1(5.0)$ & $2(5.0)$ & 0.998 \\
Altered Creatinine levels & $4(20.0)$ & $3(7.5)$ & 0.208 \\
Altered GPT levels & $12(60.0)$ & $6(15.0)$ & 0.0007 \\
Altered GOT levels & $16(80.0)$ & $9(22.5)$ & 0.0001 \\
\hline
\end{tabular}

* estimated by Fisher's exact test; DwWS: Dengue with warning signs; NE: not estimated;

DLC: differential leukocytes counts; HCT: hematocrit; BUN: blood urea nitrogen;

GPT: glutamic-piruvic transaminase; GOT: glutamic-oxaloacetic transaminase

Table 2. Clinical and laboratory characteristics of pediatric patients with severe dengue and dengue with warning signs, external validation group, Peru, 2018

\begin{tabular}{|c|c|c|c|}
\hline Variables & $\begin{array}{l}\text { Severe Dengue } \\
\text { n (\%) }\end{array}$ & $\begin{array}{l}\text { DwWS } \\
\text { n (\%) }\end{array}$ & p-value* \\
\hline Fever & $20(100.0)$ & $40(100.0)$ & $\mathrm{NE}$ \\
\hline Asthenia & $6(30.0)$ & $1(2.5)$ & 0.004 \\
\hline Epistaxis & $2(10.0)$ & $2(5.0)$ & 0.595 \\
\hline Petechias & $0(0.0)$ & $1(2.5)$ & $\mathrm{NE}$ \\
\hline Rash & $5(25.0)$ & $15(37.5)$ & 0.395 \\
\hline Myalgias & $17(85.0)$ & $29(72.5)$ & 0.347 \\
\hline Arthralgias & $14(70.0)$ & $34(85.0)$ & 0.189 \\
\hline Lethargy & $9(45.0)$ & $11(27.5)$ & 0.0004 \\
\hline Unconsciousness & $3(15.0)$ & $1(2.5)$ & 0.103 \\
\hline Persistent vomiting & $13(65.0)$ & $30(75.0)$ & 0.545 \\
\hline Hematemesis & $1(5.0)$ & $4(10.0)$ & 0.656 \\
\hline Hematuria & $2(10.0)$ & $1(2.5)$ & 0.255 \\
\hline Abdominal pain & $13(65.0)$ & $30(75.0)$ & 0.545 \\
\hline Shock & $3(15.0)$ & $0(0.0)$ & $\mathrm{NE}$ \\
\hline Hypothermia & $4(20.0)$ & $0(0.0)$ & $\mathrm{NE}$ \\
\hline Decreased diuresis & $3(15.0)$ & $2(5.0)$ & 0.322 \\
\hline Respiratory distress & $10(50.0)$ & $9(22.5)$ & 0.042 \\
\hline Cold extremities & $7(35.0)$ & $0(0.0)$ & $\mathrm{NE}$ \\
\hline $\mathrm{SBP}-\mathrm{DBP}<20 \mathrm{mmHg}$ & $5(25.0)$ & $0(0.0)$ & $\mathrm{NE}$ \\
\hline
\end{tabular}




\begin{tabular}{llll}
\hline Variables & $\begin{array}{l}\text { Severe Dengue } \\
\text { n (\%) }\end{array}$ & $\begin{array}{l}\text { DwWS } \\
\text { n (\%) }\end{array}$ & p-value* \\
\hline Weak pulse & $5(25.0)$ & $0(0.0)$ & NE \\
Thrombocytopenia & $2(10.0)$ & $11(27.5)$ & 0.186 \\
HCT rise 20\% or more & $5(25.0)$ & $21(52.5)$ & 0.056 \\
\hline
\end{tabular}

* estimated by Fisher's exact test; DwWS: Dengue with warning signs; SBP: systolic blood pressure; DBP: diastolic blood pressure; HCT: hematocrit; NE: not estimated

\subsection{Serum Protein Carbonyls Concentrations (Derivation Group)}

In cases and controls, the medians serum concentration for PCOs were $23.49 \mathrm{nmol} / \mathrm{mL}$ (IQR: 21.53 to 26.91 ) and $16.26 \mathrm{nmol} \mathrm{mL}$ (IQR: 14.41 to 18.16 ), respectively. The concentration of protein-standardized PCOs in pediatric patients with severe dengue was $7.30 \mathrm{nmol} / \mathrm{mg}$ of protein (IQR: 6.75 to 8.60 ) and $4.82 \mathrm{nmol} / \mathrm{mg}$ of protein (IQR: 4.52 to 5.31) for patients with dengue with warning signs.

The analysis showed that serum PCOs concentrations of the cases were significantly higher than control group (non-standardized values: $\mathrm{CI} 95 \%{ }_{\text {diff }} 4.03$ to $9.08 \mathrm{nmol} / \mathrm{mL}$; protein-standardized values: $\mathrm{CI} 95 \%{ }_{\text {diff }} 1.45$ to 2.95 $\mathrm{nmol} / \mathrm{mg}$ of protein).

In line with the aforementioned, we found a strong statistical association between the occurrence of severe dengue and serum PCOs concentrations (non-standardized values: Rosenthal's correlation coefficient $=0.5 ; \mathrm{p}=0.0001$; protein-standardized values: Rosenthal's correlation coefficient $=0.5 ; \mathrm{p}=0.0002$ ) (Figures $1 \mathrm{a}$ and $1 \mathrm{~b}$ ).

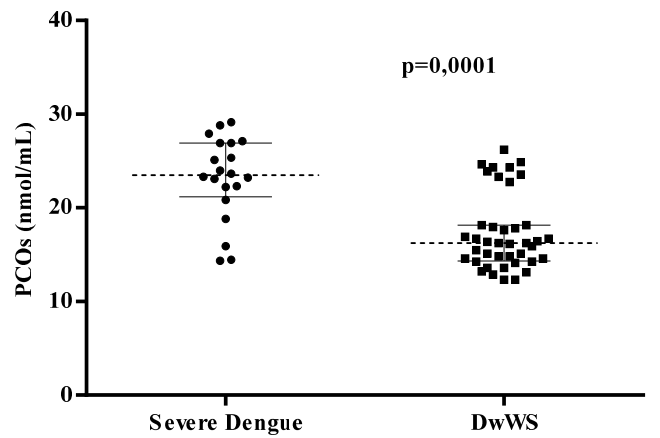

(a)

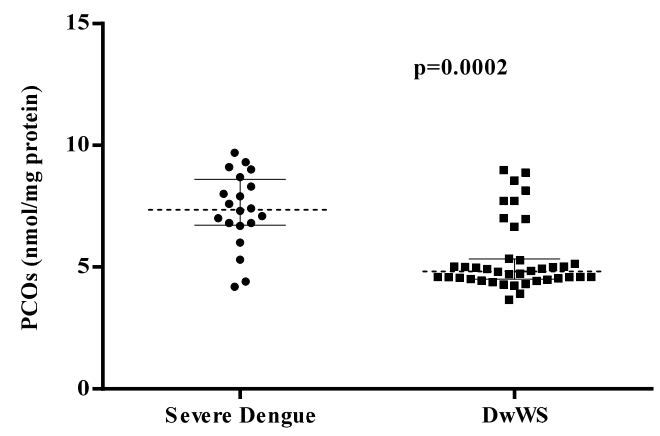

(b)

Figure 1. Serum protein carbonyls concentrations in pediatric patients with severe dengue and dengue with warning signs (DwWS). Derivation group, Barranquilla, 2014-2016. (a): non-standardized serum concentrations;

(b): protein-standardized serum concentrations. Errors bars represent median and interquartile range

\subsection{Serum Manganese Superoxide Dismutase, Cu/Zn Superoxide Dismutase, and Total Superoxide Dismutase Concentrations (Derivation Group)}

The average MnSOD activity $( \pm \mathrm{SD})$ in the sera of patients with severe dengue and patients with dengue with warning signs were $1.39 \pm 0.05 \mathrm{U} / \mathrm{mL}$ and $1.41 \pm 0.10 \mathrm{U} / \mathrm{mL}$, respectively. No statistically significant difference could be demonstrated between these two values of enzymatic activity (CI95\% $\%_{\text {diff }}-0.02$ to $0.06, \mathrm{t}=0.988, \mathrm{df}=58$; $\mathrm{p}=0.327$ ) (See Supplementary Figure S1a). Studied cases had a mean concentrations of $3.21 \pm 0.05 \mathrm{U}$ of total $\mathrm{SOD} / \mathrm{mL}$ and $1.82 \pm 0.07 \mathrm{U}$ of $\mathrm{Cu} / \mathrm{ZnSOD} / \mathrm{mL}$. In the controls, serum levels of total SOD of $3.18 \pm 0.05 \mathrm{U} / \mathrm{mL}$ and $1.78 \pm 0.10 \mathrm{U}$ of $\mathrm{Cu} / \mathrm{ZnSOD} / \mathrm{mL}$ were found.

We obtained evidence of a moderate to strong statistical association of occurrence of severe dengue with the enzyme activity of total SOD $(\mathrm{t}=1.989 ; \mathrm{df}=39.83 ; \mathrm{p}=0.054$, Cohen's $\mathrm{d}=0.7)$ and evidence of a weak to moderate statistical association with the enzymatic activity of $\mathrm{Cu} / \mathrm{ZnSOD}(\mathrm{t}=1.996 ; \mathrm{df}=52.96 ; \mathrm{p}=0.051$; Cohen's $\mathrm{d}=0.4)$, accompanied with scarce absence of statistically significant difference (total SOD-cases vs controls: CI95\% $\%_{\text {diff }}$ -0.0004 to $0.05 \mathrm{U} / \mathrm{mL}$; $\mathrm{Cu} / \mathrm{ZnSOD}$-cases vs. controls: $\mathrm{Cl} 95 \%{ }_{\text {diff }}-0.0002$ to $0.09 \mathrm{U} / \mathrm{mL}$ ) (See Supplementary Figures S1b and S1c). 


\subsection{Serum Lipid Hydroperoxides Concentrations (Derivation Group)}

The mean concentrations of LOOHs of $61.20 \pm 6.88 \mu \mathrm{M}$ and $59.79 \pm 7.08 \mu \mathrm{M}$ were found in children with severe dengue and in children with dengue with warning signs, respectively. Neither, statistical association was found between serum LOOHs concentrations with the occurrence of severe dengue $(\mathrm{t}=-0.735 ; \mathrm{df}=58 ; \mathrm{p}=0.465)$ or statistically significant difference when comparing these serum values (cases vs. controls: CI95\% $\%_{\text {diff }}-5.26$ to 2.43 $\mu \mathrm{M})$ (See Supplementary Figure S2).

\subsection{Serum Protein Carbonyls Concentrations (External Validation Group)}

In cases and controls, the medians serum concentration for PCOs were $20.02 \mathrm{nmol} / \mathrm{mL}$ (IQR: 18.34 to 21.59 ) and $13.62 \mathrm{nmol} / \mathrm{mL}$ (IQR: 12.11 to 16.26 ), respectively. The concentration of protein-standardized PCOs in patients with severe dengue was $6.95 \mathrm{nmol} / \mathrm{mg}$ of protein (IQR: 6.63 to 7.56 ) and $4.47 \mathrm{nmol} / \mathrm{mg}$ of protein (IQR: 4.00 to 5.19) for patients with dengue with warning signs.

The analysis showed that serum PCOs concentrations of the cases were significantly higher than control group (non-standardized values: CI95\% $\%_{\text {diff }} 3.42$ to $7.34 \mathrm{nmol} / \mathrm{mL}$; protein-standardized values: CI95\% $\%_{\text {diff }} 1.59$ to 2.84 $\mathrm{nmol} / \mathrm{mg}$ of protein). Again, we found a strong statistical association between the occurrence of severe dengue and serum PCOs concentrations (non-standardized values: Rosenthal's correlation coefficient $=0.6 ; \mathrm{p}<0.0001$; protein-standardized values: Rosenthal's correlation coefficient $=0.6 ; \mathrm{p}<0.0001$ ) (Figures $2 \mathrm{a}$ and $2 \mathrm{~b}$ ).

Something similar occurred when comparing medians for serum PCOs levels between pediatric cases and controls (non-standardized values: $20.13 \mathrm{nmol} / \mathrm{mL}$ vs. $12.11 \mathrm{nmol} / \mathrm{mL}$, respectively; CI95\% ${ }_{\text {diff }} 5.33$ to 9.42 ; Rosenthal's correlation coefficient $=0.6 ; \mathrm{p}=0.001$; protein-standardized values: $8.40 \mathrm{nmol} / \mathrm{mg}$ of protein vs. $4.29 \mathrm{nmol} / \mathrm{mg}$ of protein, respectively; CI95\% ${ }_{\text {diff }} 2.27$ to 4.82 ; Rosenthal's correlation coefficient $=0.7 ; \mathrm{p}<0.0001$ ) and between adult cases and controls (non-standardized values: $19.74 \mathrm{nmol} / \mathrm{mL}$ vs. $15.00 \mathrm{nmol} / \mathrm{mL}$, respectively; CI95\% $\%_{\text {diff }} 0.62$ to $6.17 \mathrm{nmol} / \mathrm{mL}$; Rosenthal's correlation coefficient $=0.5 ; \mathrm{p}=0.007$; protein-standardized values: $6.42 \mathrm{nmol} / \mathrm{mg}$ of protein vs. $4.63 \mathrm{nmol} / \mathrm{mg}$ of protein, respectively; CI95\% ${ }_{\text {diff }} 0.84$ to 2.43 ; Rosenthal's correlation coefficient $=0.5$; $\mathrm{p}=0.001)$.

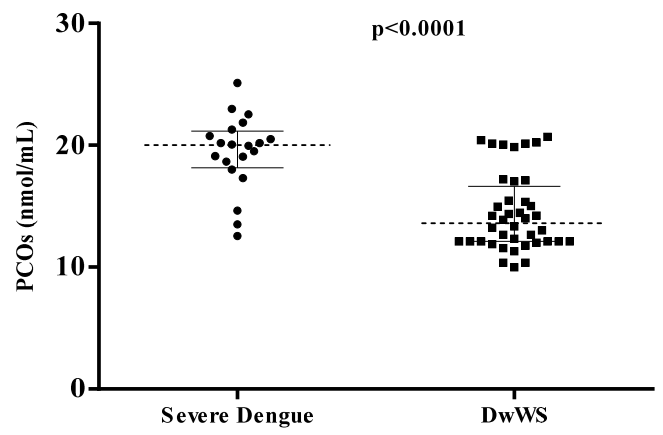

(a)

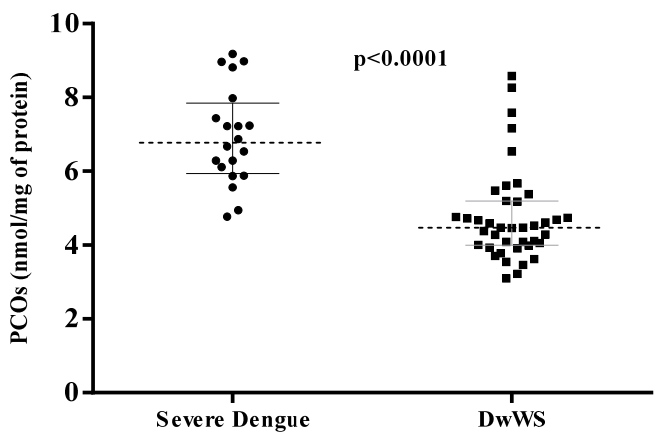

(b)

Figure 2. Serum protein carbonyls concentrations in patients with severe dengue and dengue with warning signs (DwWS). External validation group, Peru, 2018. (a): non-standardized serum concentrations; (b): protein-standardized serum concentrations. Errors bars represent median and interquartile range

\subsection{Serum Manganese Superoxide Dismutase, Cu/Zn Superoxide Dismutase, and Total Superoxide Dismutase Concentrations (External Validation Group)}

The average MnSOD activity ( \pm SD) in the sera of patients with severe dengue and patients with dengue with warning signs were $1.65 \pm 0.05 \mathrm{U} / \mathrm{mL}$ and $1.61 \pm 0.13 \mathrm{U} / \mathrm{mL}$, respectively. No statistically significant difference could be demonstrated between the severity of dengue and SODs activities (MnSOD: CI95\% $\%_{\text {diff }}-0.08$ to 0.01 ; $\mathrm{t}=-1.631 ; \mathrm{df}=54.25 ; \mathrm{p}=0.109$; total SOD: $\mathrm{CI} 95 \%{ }_{\text {diff }}-0.03$ to $0.01 ; \mathrm{t}=-1.365 ; \mathrm{df}=28.56 ; \mathrm{p}=0.183 ; \mathrm{Cu} / \mathrm{ZnSOD}$ : $\mathrm{C} 195 \%{ }_{\text {diff }}-0.02$ to $0.07 ; \mathrm{t}=0.973 ; \mathrm{df}=56.71 ; \mathrm{p}=0.335$ ) (See Supplementary Figures S3a, S3b and S3c).

\subsection{Serum Lipid Hydroperoxides Concentrations (External Validation Group)}

Neither, statistical association was found between serum LOOHs concentrations with the occurrence of severe dengue $(\mathrm{t}=-0.123 ; \mathrm{df}=58 ; \mathrm{p}=0.903)$ or statistically significant difference between the cases and controls $(33.21 \pm$ $11.94 \mu \mathrm{M}$ vs $32.82 \pm 11.49 \mu \mathrm{M}$, respectively, CI95\% $\%_{\text {diff }}-6.77$ to $5.99 \mu \mathrm{M}$ ) (See Supplementary Figure S4). 


\subsection{Optimal Cut-off Level and Area under the Curve of Protein Carbonyls (Derivation Group)}

The optimum cut-off value of non-standardized PCOs concentrations for severe dengue was $18.50 \mathrm{nmol}$ of PCOs $/ \mathrm{mL}(\mathrm{J}=0.63$ ) (Figure 3) that carried sensitivity and specificity of $85.0 \%$ (CI95\% 66.9\% to 100.0\%) and 72.5\% (CI95\% 57.4\% to 87.6\%), respectively with an AUC of 80.6\% (CI95\% 68.6\% to $92.6 \%$ ). For protein-standardized PCOs concentrations, the optimum cut-off value was $5.29 \mathrm{nmol} / \mathrm{mg}$ of protein $(\mathrm{J}=0.65)$ (Figure 4) with AUC of $80.2 \%$ (CI95\% $67.2 \%$ to $93.2 \%$ ) and sensitivity and specificity of $90.0 \%$ (CI95\% $74.4 \%$ to $100.0 \%$ ) and $75.0 \%$ (CI95\% 60.3\% to $89.7 \%$ ), respectively.

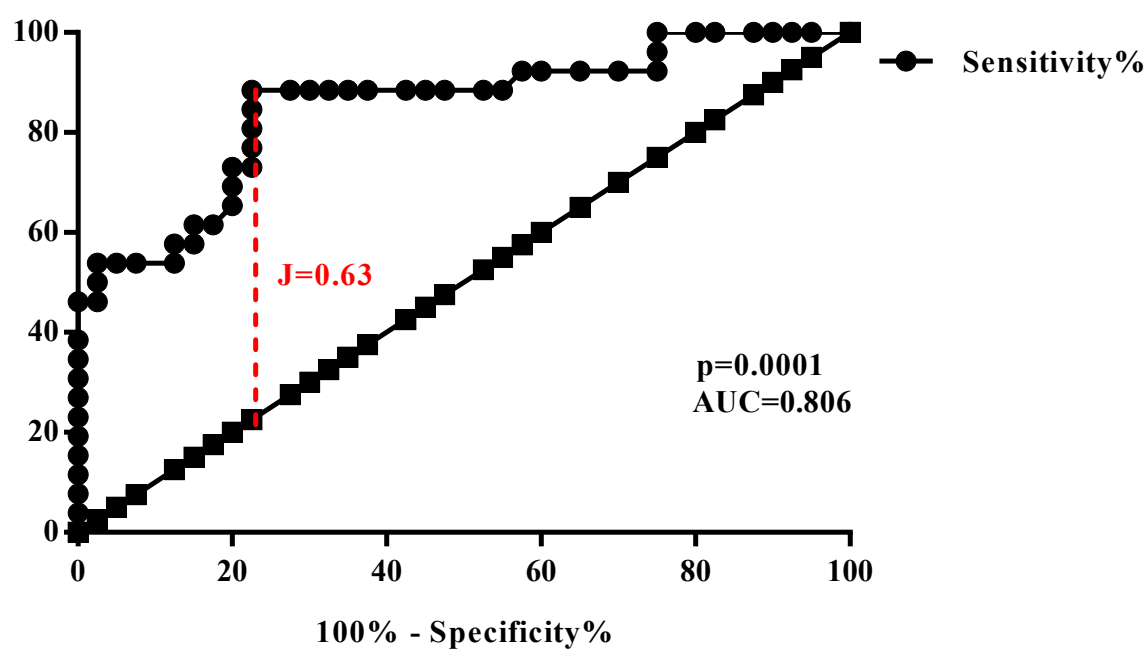

Figure 3. Receiver-operating characteristics (ROC) curve of non-standardized serum concentrations of protein carbonyls (PCOs) in pediatric patients with severe dengue and dengue patients with warning signs. Derivation group, Barranquilla-Colombia, 2014-2016

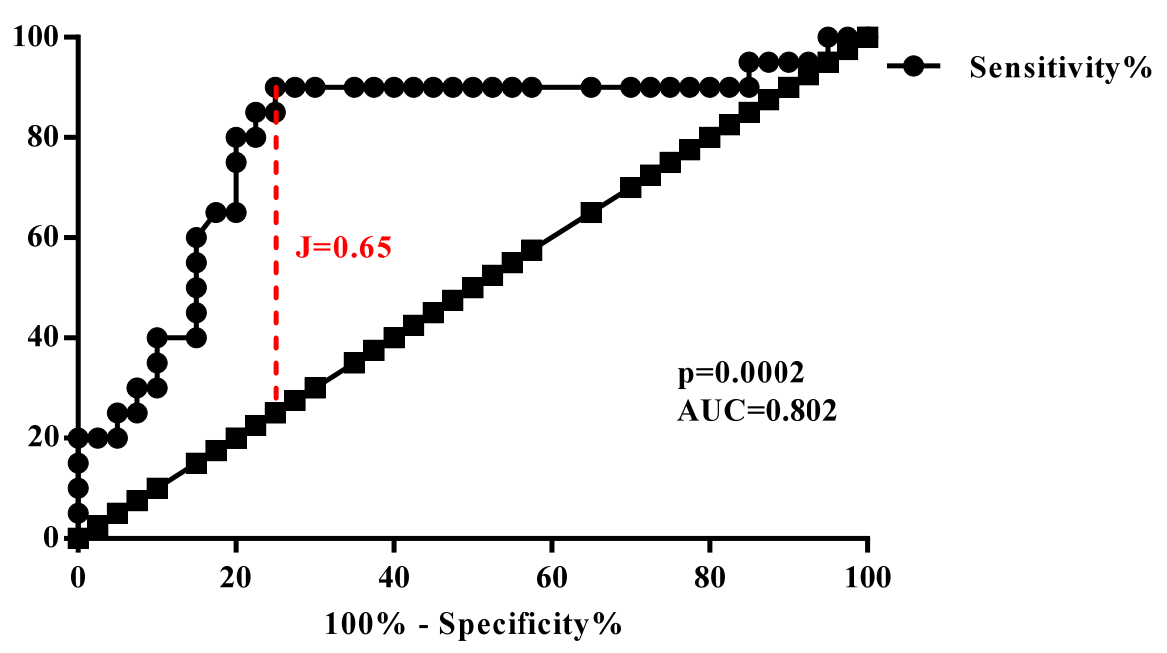

Figure 4. Receiver-operating characteristics (ROC) curve of protein-standardized serum concentrations of protein carbonyls (PCOs) in patients with severe dengue and dengue patients with warning signs. Derivation group,

Barranquilla-Colombia, 2014-2016

\subsection{Logistic Regression Analysis of Oxidative Stress Biomarkers (Derivation Group)}

PCOs was the only biomarker with prognostic capacity for severe dengue among pediatric patients. Table 3 shows the results of the binary logistic regression using the two optimal cut-off values estimated for serum PCOs concentrations, including bootstrapping results. By contrast, the remaining biomarkers did not meet inclusion 
criteria of a variable in the prognostic model (MnSOD: $\mathrm{p}=0.216$; total SOD: $\mathrm{p}=0.448$; $\mathrm{Cu} / \mathrm{ZnSOD}$ : $\mathrm{p}=0.188$; LOOHs: $\mathrm{p}=0.643$ ).

A cut-off value for protein-standardized serum PCOs concentrations of $5.29 \mathrm{nmol} / \mathrm{mg}$ of protein (PM-2: dichotomized predictor) was the best in identifying pediatric patients with severe dengue, in comparison with continuous predictor $\left(90.0 \%\right.$ vs. $55.0 \%$, respectively; CI95\% $\%_{\text {diff }} 7.2 \%$ a $\left.57.0 \%\right)$.

Table 3. Binary logistic regression models to predict the probability of severe dengue in pediatric patients, using optimal cut-off points of serum concentrations of protein carbonyls. Derivation group, Barranquilla-Colombia, 2014-2016

\begin{tabular}{|c|c|c|c|c|c|}
\hline \multicolumn{6}{|l|}{ First prognostic model (PM-1) } \\
\hline Predictor (cut-off point) & B & Wald statistic (df) & p-value & $\operatorname{Exp}(B)$ & CI95\% \\
\hline PCOs $(18.50 \mathrm{nmol} / \mathrm{mL})$ & 2.70 & $14.127(1)$ & 0.0002 & 14.94 & $3.65-61.20$ \\
\hline Constant & -2.27 & $13.933(1)$ & 0.0002 & 0.103 & \\
\hline \multicolumn{6}{|c|}{ Regression equation-1: $\mathrm{Ln}(\mathrm{p} / 1-\mathrm{p})=-2.27+2.70($ serum PCOs levels of patient $\geq 18.50 \mathrm{nmol} / \mathrm{mL})$} \\
\hline \multicolumn{6}{|l|}{ Bootstrapping (10 000 samples) } \\
\hline Predictor (cut-off point) & Bias & p-value & & & \\
\hline PCOs $(18.50 \mathrm{nmol} / \mathrm{mL})$ & 0.97 & 0.0001 & & & \\
\hline Constant & -0.95 & 0.0003 & & & \\
\hline \multicolumn{6}{|l|}{ Second prognostic model (PM-2) } \\
\hline Predictor (cut-off point) & B & Wald statistic (df) & p-value & $\operatorname{Exp}(B)$ & CI95\% \\
\hline PCOs $(5.29 \mathrm{nmol} / \mathrm{mg}$ of protein) & 3.30 & $15.77(1)$ & 0.0001 & 27.00 & $5.31-137.36$ \\
\hline Constant & -2.71 & $16.75(1)$ & 0.0002 & 0.07 & \\
\hline \multicolumn{6}{|c|}{ Regression equation-2: $\operatorname{Ln}(\mathrm{p} / 1-\mathrm{p})=-2.71+3.30($ serum PCOs levels of patient $\geq 5.29 \mathrm{nmol} / \mathrm{mg}$ of protein) } \\
\hline \multicolumn{6}{|l|}{ Bootstrapping (10 000 samples) } \\
\hline Predictor (cut-off point) & Bias & p-value & & & \\
\hline PCOs $(5.29 \mathrm{nmol} / \mathrm{mg}$ of protein) & 0.45 & 0.0001 & & & \\
\hline Constant & -0.42 & 0.001 & & & \\
\hline
\end{tabular}

PCOs: protein carbonyls; df: degree of freedom.

\subsection{Calibration and Discrimination of Prognostic Model (Derivation Group)}

Approximately, $47.2 \%$ of the variance of the criterion variable (severity of dengue) can be explained by PM-2 (Nagelkerke pseudo- $\mathrm{R}^{2}=0.472$ ) with a c-statistic of $0.825(\mathrm{CI} 95 \% 0.729$ to $0.921 ; \mathrm{p}<0.0001)$.

The predicted probability of severe dengue in a pediatric patient $(\leq 15$ years $)$ with serum PCOs concentrations greater than or equal to $5.29 \mathrm{nmol} / \mathrm{mg}$ of protein was 0.643 (CI95\% 0.454 to 0.796 ), whereas the predicted probability of severe dengue in a pediatric patient with serum levels below the optimal threshold was estimated at 0.062 (CI95\% 0.016 to 0.218; Chi-square test/omnibus test: $\mathrm{X}^{2}=24.92$; $\mathrm{df}=1 ; \mathrm{p}<0.0001$ ).

\subsection{Evaluation of Transportability of Prognostic Model (External Validation Group)}

In applying of PM-2 in external validation group, an AUC of $83.8 \%$ (CI95\% $74.4 \%$ to $93.2 \%$; $<<0.0001$ ) was calculated. The predicted probability of severe dengue in a patient with serum PCOs concentrations greater than or equal to $5.29 \mathrm{nmol} / \mathrm{mg}$ of protein was 0.667 (CI95\% 0.473 to 0.817 ), whereas the predicted probability of severe dengue in a patient with serum PCOs concentrations below the optimal threshold was estimated at 0.061 (CI95\% 0.015 to 0.212 ; Chi-square test/omnibus test: $\mathrm{X}^{2}=26.92 ; \mathrm{df}=1 ; \mathrm{p}<0.0001$ ).

Moreover, these probability values are similar to those estimated among pediatric patients (derivation group) ( $\geq 5.29 \mathrm{nmol}$ of PCOs $/ \mathrm{mg}$ of protein: CI $95 \% \%_{\text {diff }}-0.253$ to $0.296 ;<5.29 \mathrm{nmol}$ of PCOs $/ \mathrm{mg}$ of protein: CI $95 \%_{\text {diff }}$ -0.126 to 0.128 ). No evidence of statistical association was found between the discriminative capacity of PM-2 with the two age groups evaluated in the external validation group ( $\leq 15$ years of age vs. $>15$ years of age: $92.5 \%$ vs. 
$77.9 \%$, respectively; Chi-square test: $\mathrm{X}^{2}=3.16 ; \mathrm{df}=1 ; \mathrm{p}=0.076$ ).

\subsection{Double Cross-Validation}

In line with this strategy, the optimum cut-off value was $5.77 \mathrm{nmol}$ of PCOs $/ \mathrm{mg}$ of protein $(\mathrm{J}=0.73)$ (Figure 5) with AUC of $90.0 \%$ (CI95\% $81.8 \%$ to $98.2 \%$ ) and sensitivity and specificity values of $90.0 \%$, for each one (sensitivity: CI95\% $74.4 \%$ to $100.0 \%$ and specificity: CI95\% $79.5 \%$ to $100.0 \%$ ).

Table 4 shows the results of the binary logistic regression using the estimated optimal diagnosis point (5.77 nmol of PCOs $/ \mathrm{mg}$ of protein), including bootstrapping results. Approximately, $67.4 \%$ of the variance of the criterion variable (severity of dengue) can be explained by PM-3 (Nagelkerke pseudo- $\mathrm{R}^{2}=0.674$ ) with c-statistic $=0.900$ (CI95\% 0.806 to $0.994 ; \mathrm{p}<0.0001$ ).

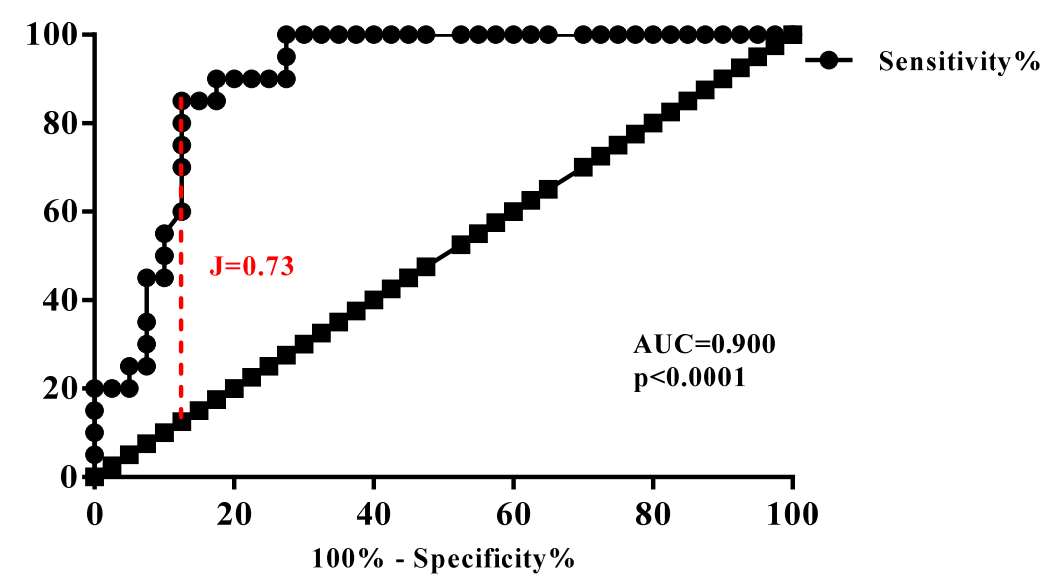

Figure 5. Receiver-operating characteristics (ROC) curve of serum concentrations of protein carbonyls (PCOs) in patients with severe dengue and dengue patients with warning signs. Retrospective validation. Derivation group,

$$
\text { Peru, } 2018
$$

Table 4. Binary logistic regression models to predict the probability of severe dengue in patients, using optimal cut-off points of serum concentrations of protein carbonyls. External validation group, Peru, 2018

\begin{tabular}{llllll}
\hline Third prognostic model (PM-3) & & & & & \\
\hline Predictor (cut-off point) & B & Wald statistic (df) & p-value & Exp(B) & C195\% \\
PCOs (5.77 nmol/mg of protein) & 4.39 & $23.17(1)$ & $<0.0001$ & 81.00 & $13.54-484.76$ \\
Constant & -2.89 & $15.83(1)$ & 0.0001 & 0.056 & \\
\hline Regression equation-3: $\mathrm{Ln}(\mathrm{p} / 1-\mathrm{p})=-2.89$ & +4.39 (serum PCOs levels of patient $\geq 5.77 \mathrm{nmol} / \mathrm{mg}$ of protein) & \\
\hline Bootstrapping (10 000 samples) & & & & \\
Predictor (cut-off point) & Bias & p-value & & \\
PCOs (5.77 nmol/mg of protein) & 2.74 & 0.0001 & & \\
Constant & -2.37 & 0.0004 & &
\end{tabular}

PCOs: protein carbonyls; df: degree of freedom.

In applying of PM-3 among pediatric patients from Barranquilla-Colombia (external validation group), an AUC of $82.5 \%$ (CI95\% $72.3 \%$ to $98.7 \% ; \mathrm{p}<0.0001)$ was calculated. The predicted probability of severe dengue in a patient with serum levels greater than or equal to $5.77 \mathrm{nmol} / \mathrm{mg}$ of protein was 0.680 (CI95\% 0.478 to 0.831 ), whereas the predicted probability of severe dengue in a patient with lower serum levels to the optimum threshold was estimated at 0.086 (CI95\% 0.028 to 0.234 ). These probability values are similar to those estimated in the derivation group ( $\geq 5.77 \mathrm{nmol}$ of PCOs $/ \mathrm{mg}$ of protein: CI $95 \%_{\text {diff }}-0.166$ to $0.349 ;<5.77 \mathrm{nmol}$ of PCOs $/ \mathrm{mg}$ of protein: CI $95 \%_{\text {diff }}$ -0.100 to 0.154$)$.

Table 5 shows the results obtained from the comparison of the discriminative capacity of the prognostic models, 
based on the optimal diagnostic points, estimated in the derivation group and transported to the validation group, by the double cross-validation strategy (prospective and retrospective).

Table 5. Comparison of discriminatory capacity of binary logistic regression models to predict the probability of severe dengue in patients, using optimal cut-off points of adjusted serum concentrations of protein carbonyls. Prospective and retrospective validation

\begin{tabular}{lll}
\hline Validation strategy & Prospective & Retrospective \\
\hline Study population & PM-2 & PM-3 \\
& c-statistic (CI95\%) & c-statistic (CI95\%) \\
Derivation group & $0.825(0.729$ to 0.921$)$ & $0.900(0.818$ to 0.982$)$ \\
External validation group & $0.838(0.744$ to 0.932$)$ & $0.825(0.723$ to 0.987$)$ \\
p-value & 0.855 & 0.262 \\
$\mathrm{X}^{2}(\mathrm{df})$ & $0.03(1)$ & $1.26(1)$ \\
\hline
\end{tabular}

PCOs: protein carbonyls; df: degree of freedom; $\mathrm{X}^{2}$ : Chi-square statistic; AUC: area under the curve; PM: prognostic model.

\section{Discussion}

This study continues our examination of biomarkers of oxidative stress as prognostic tool for dengue severity, using regression models for predicting medical outcomes.

Serum levels of PCOs were significantly higher in patients with severe dengue than in patients with dengue with warning signs, in both the derivation group and validation group. The above shows coherence with the evidence published in patients with DENV infection and healthy adults, during a DENV-3 outbreak (Rajendiran et al., 2008; Soundravally, Sankar, Hoti, et al., 2008). Although median serum PCOs concentrations estimated in this study cannot be compared with other reports (Rajendiran et al., 2008; Santhosh, 2016; Soundravally, Sankar, Hoti, et al., 2008), due to the different measures of central tendency and dispersion used, we suggest that the most severe cases of dengue present a higher concentration of irreversibly oxidized proteins in comparison to non-severe cases.

Recently, Cherupanakkal, et al. (Cherupanakkal et al., 2017), reported that MnSOD gene expression was not associated with severity of dengue disease in children and adults. In addition to the above, we have not found statistically significant differences in MnSOD activity between patients with severe dengue and those with dengue with warning signs, in both adults and children. All in all, the above evidences allow us to suggest that the antioxidant activity of MnSOD does not participate in the pathogenesis of severe dengue.

In addition to the explanations reported by Cherupanakkal, et al. (Cherupanakkal et al., 2017), it is necessary to consider the presence of IgM autoantibodies against MnSOD, which could inhibit the protective effects of MnSOD. These antibodies have been reported in patients with acute viral infections (Ritter et al., 1994; Semrau et al., 1998), and it has been shown that may contribute to the oxidative damage of endothelial cells (Dalpke et al., 2003). Likewise, no significant differences were found in total SOD and $\mathrm{Cu} / \mathrm{ZnSOD}$ activities between cases and controls In this regard, elevated levels of TNF- $\alpha$ and IFN- $\gamma$ in dengue-infected patients could decrease the gene expression of antioxidant enzymes, including SOD (Ho et al., 2001).

As regards serum LOOHs levels, no statistically significant difference was found between cases and controls, in both the derivation and validation groups. It is not possible to compare our results with other studies (Gil et al., 2012; Gil et al., 2004), due some important methodological and analytical differences, such as WHO dengue case classification system, extraction procedure, and ferric ions indicator.

Here, we would like to point out that discordance has also been found in the correlation between LOOHs and PCOs concentrations in virus-infected insect cell culture (Wang, Oberley, \& Murhammer, 2001) and in blood after exhaustive aerobic and nonaerobic isometric exercises (Alessio et al., 2000). This discrepancy can be explained by certain pre-analytical errors, effects of small size sample, and the differences between the reactions involved in formation of these oxidative stress biomarkers (Dotan, Lichtenberg, \& Pinchuk, 2004).

Prognosis cut-off point of $5.29 \mathrm{nmol}$ of PCOs/mg of protein showed high sensitivity and negative predictive value. For screening purposes, these characteristics are more important than a high specificity and positive predictive value, especially in the context of serious and treatable diseases (Bravo-Grau \& Cruz Q, 2015). 
In our study, severe dengue is 27 times more likely if the pediatric patient has a serum concentration of PCOs equal to or greater than $5.29 \mathrm{nmol} / \mathrm{mg}$ of protein, compared to a pediatric patient with serum values below this cut-off point. After resampling, this prognostic cut-off point maintains its discriminative capacity for dengue severity in the pediatric population.

External validity (transportability) proves to be a critical requirement of a prognostic model, since the transportability is taken to mean the ability of a prognostic model to maintain their accuracy when applied to patients and settings different from those on which the model was developed (Terrin, Schmid, Griffith, D'Agostino, \& Selker, 2003).

Having a serum PCOs level of $5.29 \mathrm{nmol} / \mathrm{mg}$ of protein or more meant than 83 -fold increased probability of having severe dengue, both derivation and external validation groups. According to Swets (Swets, 1988), serum concentrations of PCOs could be considered useful to distinguish early disease severity among pediatric patients with dengue.

With regard to the Peruvian population, approximately, $90.0 \%$ of the time a randomly selected patient who experienced severe dengue will have a serum PCOs level greater than or equal to $5.77 \mathrm{nmol} / \mathrm{mg}$ of protein, compared to a randomly selected patient who experienced dengue with warning signs. This was found to be true in pediatric patients population used as external validation group.

Leaving aside the differences between the 1997 and 2009 WHO dengue classification schemes, we emphasize that the estimated optimal cut-points (5.29 and $5.77 \mathrm{nmol}$ of PCOs/mg of protein) are located between estimated cut-off points for predicting dengue hemorrhagic fever $(5.22 \mathrm{nmol} / \mathrm{mg}$ of protein) and dengue shock syndrome (6.13 $\mathrm{nmol} / \mathrm{mg}$ protein) among adult patients with dengue virus infection (Soundravally et al., 2008). It is worth pointing out here that most patients who meet the criteria for severe dengue can be categorized as dengue hemorrhagic fever patients (Tsai et al., 2013).

The four main limitations of our study are: (I) the heterogeneity between derivation and external validation groups in regard to age; (II) molecular detection of DENV and other arboviruses was not performed on serum samples obtained from 60 pediatric patients positive for NS1-DENV and/or anti-dengue IgM; (III) the level of completeness for the data set obtained through public surveillance system for dengue disease in Peru; and (IV) the use of hospital controls can lead to a problem of representativeness, that potentially affect external validity of the study (Gomez, 2003). Despite these limitations, our estimates do provide prognostic models based on two diagnostic thresholds showed a high discriminatory capacity of dengue severity, external reproducibility, geographic transportability, and typical characteristics of diagnostic validity and safety of screening tests.

Supplementary Materials, Figure S1: Comparison between serum enzymatic activities of dismutase superoxide (a: mitochondrial SOD; b: total SOD; c: cytosolic SOD) in pediatric patients with severe dengue and dengue patients with warning signs. Derivation group, Barranquilla-Colombia, 2014-2016; Figure S2: Comparison between serum concentrations of lipid hydroperoxides in pediatric patients with severe dengue and dengue patients with warning signs. Derivation group, Barranquilla-Colombia, 2014-2016; Figure S3: Comparison between serum enzymatic activities of dismutase superoxide (a: mitochondrial SOD; b: total SOD; c: cytosolic SOD) in patients with severe dengue and dengue patients with warning signs. External validation group, Peru, 2018; Figure S4: Comparison between serum concentrations of lipid hydroperoxides in patients with severe dengue and dengue patients with warning signs. External validation group, Peru, 2018.

\section{Funding}

This research received no external funding.

\section{Competing Interests Statement}

The authors declare no conflict of interest.

\section{References}

Alera, M. T., Srikiatkhachorn, A., Velasco, J. M., Tac-An, I. A., Lago, C. B., Clapham, H. E., . . Yoon, I.-K. (2016). Incidence of Dengue Virus Infection in Adults and Children in a Prospective Longitudinal Cohort in the Philippines. PLoS Negl Trop Dis, 10(2), e0004337. https://doi.org/10.1371/journal.pntd.0004337

Alessio, H. M., Hagerman, A. E., Fulkerson, B. K., Ambrose, J., Rice, R. E., \& Wiley, R. L. (2000). Generation of reactive oxygen species after exhaustive aerobic and isometric exercise. Med Sci Sports Exerc, 32(9), 1576-1581.

Bravo-Grau, S., \& Cruz Q, J. P. (2015). Estudios de exactitud diagnóstica: Herramientas para su Interpretación. 
Revista chilena de radiología, 21, 158-164.

Cunha, G. M., Silva, V. M., Bessa, K. D., Bitencourt, M. A., Macedo, U. B., Freire-Neto, F. P., . . Freire, A. C. (2012). Levels of oxidative stress markers: correlation with hepatic function and worm burden patients with schistosomiasis. Acta Parasitol, 57(2), 160-166. https://doi.org/10.2478/s11686-012-0026-5

Cherupanakkal, C., Ramachadrappa, V., Kadhiravan, T., Parameswaran, N., Parija, S. C., Pillai, A. B., \& Rajendiran, S. (2017). A Study on Gene Expression Profile of Endogenous Antioxidant Enzymes: CAT, MnSOD and GPx in Dengue Patients. Indian Journal of Clinical Biochemistry, 32(4), 437-445. https://doi.org/10.1007/s12291-017-0633-X

Dalpke, A. H., Thomssen, R., \& Ritter, K. (2003). Oxidative injury to endothelial cells due to Epstein-Barr virusinduced autoantibodies against manganese superoxide dismutase. Journal of Medical Virology, 71(3), 408-416. https://doi.org/doi:10.1002/jmv.10501

Dalrymple, N. A., \& Mackow, E. R. (2012). Roles for endothelial cells in dengue virus infection. Adv Virol, 2012, 840654. https://doi.org/10.1155/2012/840654

Dalle-Donne, I., Rossi, R., Giustarini, D., Milzani, A., \& Colombo, R. (2003). Protein carbonyl groups as biomarkers of oxidative stress. Clin Chim Acta, 329(1-2), 23-38.

Dotan, Y., Lichtenberg, D., \& Pinchuk, I. (2004). Lipid peroxidation cannot be used as a universal criterion of oxidative stress. Progress in Lipid Research, 43(3), 200-227. https://doi.org/10.1016/j.plipres.2003.10.001

Fabbri, C., de Cassia Mascarenhas-Netto, R., Lalwani, P., Melo, G. C., Magalhaes, B. M., Alexandre, M. A., .. . Lima, E. S. (2013). Lipid peroxidation and antioxidant enzymes activity in Plasmodium vivax malaria patients evolving with cholestatic jaundice. Malar J, 12(1), 315. https://doi.org/10.1186/1475-2875-12-315

Gaskin, C. J., \& Happell, B. (2014). Power, effects, confidence, and significance: An investigation of statistical practices in nursing research. International Journal of Nursing Studies, 51(5), 795-806. https://doi.org/10.1016/j.ijnurstu.2013.09.014

Gil, L., León, O. S., Pérez, J., Milián, L. C., González, I., \& Guevara, M. (2012). Characterization of oxidative stress in different clinical conditions, using redox indexes of diagnostic value. Biotecnología Aplicada, 29(3), 175-183.

Gil, L., Martinez, G., Tapanes, R., Castro, O., Gonzalez, D., Bernardo, L., . . Guzman, M. G. (2004). Oxidative stress in adult dengue patients. Am J Trop Med Hyg, 71(5), 652-657.

Girotti, A. W. (1998). Lipid hydroperoxide generation, turnover, and effector action in biological systems. $J$ Lipid Res, 39(8), 1529-1542.

Gomez, M., Danglot, C., Huerta, S. G., \& García de la Torre, S. (2003). El estudio de casos y controles. Su diseño, análisis e interpretación, en investigación clínica. Rev Mex Pediatr, 70(5), 257-263.

Gori, T., \& Munzel, T. (2011). Oxidative stress and endothelial dysfunction: therapeutic implications. Ann Med, 43(4), 259-272. https://doi.org/10.3109/07853890.2010.543920

Halstead, S. B. (2013). Dengue: the syndromic basis to pathogenesis research. Inutility of the 2009 WHO case definition. Am J Trop Med Hyg, 88(2), 212-215. https://doi.org/10.4269/ajtmh.12-0197

Hanley, J. A., \& McNeil, B. J. (1983). A method of comparing the areas under receiver operating characteristic curves derived from the same cases. Radiology, 148(3), 839-843. https://doi.org/10.1148/radiology.148.3.6878708

Ho, J. C. M., Zheng, S., Comhair, S. A. A., Erzurum, S. C., \& Farver, C. (2001). Differential expression of manganese superoxide dismutase and catalase in lung cancer. Cancer Research, 61(23), 8578-8585.

Hosakote, Y. M., Liu, T., Castro, S. M., Garofalo, R. P., \& Casola, A. (2009). Respiratory syncytial virus induces oxidative stress by modulating antioxidant enzymes. Am J Respir Cell Mol Biol, 41(3), 348-357. https://doi.org/10.1165/rcmb.2008-03300C

Kalugalage, T., Rodrigo, C., Vithanage, T., Somaratne, P., De Silva, H. J., Handunnetti, S., \& Rajapakse, S. (2013). Low serum total nitrite and nitrate levels in severe leptospirosis. BMC Infect Dis, $13,206$. https://doi.org/10.1186/1471-2334-13-206

Lanciotti, R. S., Calisher, C. H., Gubler, D. J., Chang, G. J., \& Vorndam, A. V. (1992). Rapid detection and typing of dengue viruses from clinical samples by using reverse transcriptase-polymerase chain reaction. $J C l i n$ Microbiol, 30(3), 545-551. 
Leo, Y. S., Gan, V. C., Ng, E. L., Hao, Y., Ng, L. C., Pok, K. Y., . . Lye, D. C. (2013). Utility of warning signs in guiding admission and predicting severe disease in adult dengue. BMC Infect Dis, 13, 498. https://doi.org/10.1186/1471-2334-13-498

Levent, G., Ali, A., Ahmet, A., Polat, E. C., Aytac, C., Ayse, E., \& Ahmet, S. (2006). Oxidative stress and antioxidant defense in patients with chronic hepatitis $\mathrm{C}$ patients before and after pegylated interferon alfa- $2 \mathrm{~b}$ plus ribavirin therapy. J Transl Med, 4, 25. https://doi.org/10.1186/1479-5876-4-25

Macdonald, J., Galley, H. F., \& Webster, N. R. (2003). Oxidative stress and gene expression in sepsis. Br J Anaesth, 90(2), 221-232.

Machado, F. S., Tanowitz, H. B., \& Ribeiro, A. L. (2013). Pathogenesis of chagas cardiomyopathy: role of inflammation and oxidative stress. $J$ Am Heart Assoc, 2(5), e000539. https://doi.org/10.1161/JAHA.113.000539

Mesquita, C. S., Oliveira, R., Bento, F., Geraldo, D., Rodrigues, J. V., \& Marcos, J. C. (2014). Simplified 2,4-dinitrophenylhydrazine spectrophotometric assay for quantification of carbonyls in oxidized proteins. Anal Biochem, 458, 69-71. https://doi.org/10.1016/j.ab.2014.04.034

Molyneux, D. (2013). Neglected tropical diseases. Community Eye Health, 26(82), 21-24.

Nuñez, E., Steyerberg, E., Nuñez, J. (2011). Estrategias para la elaboración de modelos estadísticos de regresión. Revista Española de Cardiología, 64(6), 501-507.

Osborne, J. W. (2000). Prediction in Multiple Regression. Practical Assessment, Research \& Evaluation, 7(2), $1-6$.

Pawitan, J. A. (2011). Dengue virus infection: predictors for severe dengue. Acta Med Indones, 43(2), 129-135.

Pereira, E. C., Ferderbar, S., Bertolami, M. C., Faludi, A. A., Monte, O., Xavier, H. T., . . Abdalla, D. S. (2008). Biomarkers of oxidative stress and endothelial dysfunction in glucose intolerance and diabetes mellitus. Clin Biochem, 4l(18), 1454-1460. https://doi.org/10.1016/j.clinbiochem.2008.08.074

Rajendiran, S., Lakshamanappa, H. S., Zachariah, B., \& Nambiar, S. (2008). Desialylation of plasma proteins in severe dengue infection: possible role of oxidative stress. Am J Trop Med Hyg, 79(3), 372-377.

Ray, G., Kumar, V., Kapoor, A. K., Dutta, A. K., \& Batra, S. (1999). Status of antioxidants and other biochemical abnormalities in children with dengue fever. $J$ Trop Pediatr, 45(1), 4-7.

Ritter, K., Kühl, R. J., Semrau, F., Eiffert, H., Kratzin, H. D., \& Thomssen, R. (1994). Manganese superoxide dismutase as a target of autoantibodies in acute Epstein-Barr virus infection. The Journal of Experimental Medicine, 180(5), 1995-1998. https://doi.org/10.1084/jem.180.5.1995

Rodriguez-Manas, L., El-Assar, M., Vallejo, S., Lopez-Doriga, P., Solis, J., Petidier, R., . . Sanchez-Ferrer, C. F. (2009). Endothelial dysfunction in aged humans is related with oxidative stress and vascular inflammation. Aging Cell, 8(3), 226-238. https://doi.org/10.1111/j.1474-9726.2009.00466.x

Santhosh, N. K., \& Ramadas, D. (2016). Hepatic Proteins \& Protein Oxidation - Role in Dengue Fever. International Journal of Biotechnology and Biochemistry, 12(2), 161-165.

Semrau, F., Kühl, R. J., Ritter, S., \& Ritter, K. (1998). Manganese superoxide dismutase (MnSOD) and autoantibodies against MnSOD in acute viral infections. Journal of Medical Virology, 55(2), 161-167. https://doi.org/10.1002/(SICI)1096-9071(199806)55:2<161::AID-JMV13>3.0.CO;2-L

Silva, B. R., Pernomian, L., \& Bendhack, L. M. (2012). Contribution of oxidative stress to endothelial dysfunction in hypertension. Front Physiol, 3, 441. https://doi.org/10.3389/fphys.2012.00441

Soundravally, R., Hoti, S. L., Patil, S. A., Cleetus, C. C., Zachariah, B., Kadhiravan, T., . . Kumar, B. A. (2014). Association between proinflammatory cytokines and lipid peroxidation in patients with severe dengue disease around defervescence. Int J Infect Dis, 18, 68-72. https://doi.org/10.1016/j.ijid.2013.09.022

Soundravally, R., Sankar, P., Bobby, Z., \& Hoti, S. L. (2008). Oxidative stress in severe dengue viral infection: association of thrombocytopenia with lipid peroxidation. Platelets, 19(6), 447-454. https://doi.org/10.1080/09537100802155284

Soundravally, R., Sankar, P., Hoti, S. L., Selvaraj, N., Bobby, Z., \& Sridhar, M. G. (2008). Oxidative stress induced changes in plasma protein can be a predictor of imminent severe dengue infection. Acta Trop, 106(3), 156-161. https://doi.org/10.1016/j.actatropica.2008.03.001 
Sterne, J. A., \& Davey Smith, G. (2001). Sifting the evidence-what's wrong with significance tests? BMJ, 322(7280), 226-231.

Swets, J. (1988). Measuring the accuracy of diagnostic systems. Science, 240(4857), 1285-1293. https://doi.org/10.1126/science.3287615

Terrin, N., Schmid, C. H., Griffith, J. L., D'Agostino, R. B., \& Selker, H. P. (2003). External validity of predictive models: a comparison of logistic regression, classification trees, and neural networks. Journal of Clinical Epidemiology, 56(8), 721-729. https://doi.org/10.1016/S0895-4356(03)00120-3

Tsai, C. Y., Lee, I. K., Lee, C. H., Yang, K. D., \& Liu, J. W. (2013). Comparisons of dengue illness classified based on the 1997 and 2009 World Health Organization dengue classification schemes. J Microbiol Immunol Infect, 46(4), 271-281. https://doi.org/10.1016/j.jmii.2012.07.005

Valyi-Nagy, T., \& Dermody, T. S. (2005). Role of oxidative damage in the pathogenesis of viral infections of the nervous system. Histol Histopathol, 20(3), 957-967.

Wadsworth, R. M. (2008). Oxidative stress and the endothelium. Exp Physiol, 93(1), 155-157. https://doi.org/10.1113/expphysiol.2007.038687

Wang, Y., Oberley, L. W., \& Murhammer, D. W. (2001). Evidence of oxidative stress following the viral infection of two lepidopteran insect cell lines. Free Radical Biology and Medicine, 31(11), 1448-1455. https://doi.org/10.1016/S0891-5849(01)00728-6

Wong, G. H., \& Goeddel, D. V. (1988). Induction of manganous superoxide dismutase by tumor necrosis factor: possible protective mechanism. Science, 242(4880), 941-944.

World Health Organization [WHO]. (2009). Dengue Guidelines for Diagnosis, Treatment, Prevention and Control Dengue: Guidelines for Diagnosis, Treatment, Prevention and Control: New Edition (pp. 147). Geneva.

Yacoub, S., Wertheim, H., Simmons, C. P., Screaton, G. R., \& Wills, B. (2015). Microvascular and endothelial function for risk prediction in dengue: an observational study. The Lancet, 385, S102. http://dx.doi.org/10.1016/S0140-6736(15)60417-2

Yang, T. C., Lai, C. C., Shiu, S. L., Chuang, P. H., Tzou, B. C., Lin, Y. Y., . . . Lin, C. W. (2010). Japanese encephalitis virus down-regulates thioredoxin and induces ROS-mediated ASK1-ERK/p38 MAPK activation in human promonocyte cells. Microbes Infect, 12(8-9), 643-651. https://doi.org/10.1016/j.micinf.2010.04.007

Yap, B. W., \& Sim, C. H. (2011). Comparisons of various types of normality tests. Journal of Statistical Computation and Simulation, 81(12), 2141-2155. https://doi.org/10.1080/00949655.2010.520163

Zapata, J. C., Cox, D., \& Salvato, M. S. (2014). The Role of Platelets in the Pathogenesis of Viral Hemorrhagic Fevers. PLoS Negl Trop Dis, 8(6), e2858. https://doi.org/10.1371/journal.pntd.0002858

\section{Copyrights}

Copyright for this article is retained by the author(s), with first publication rights granted to the journal.

This is an open-access article distributed under the terms and conditions of the Creative Commons Attribution license (http://creativecommons.org/licenses/by/4.0/). 